\title{
Performance Evaluation of Three Vegetative Filter Strip Designs for Controlling Feedlot Runoff Pollution
}

\author{
Atikur Rahman, Shafiqur Rahman* and Md Saidul Borhan \\ Department of Agricultural and Biosystems Engineering, North Dakota State University, United States of America
}

\begin{abstract}
A vegetative filter strip (VFS) is designed to reduce transport of sediments and nutrients downstream mainly through settling, infiltration (into soil profile), adsorption (to soil and plant materials), and by plant uptake. However, the performance of a VFS greatly depends on a VFS design and climatic conditions of a region. In this paper, relative performance of three VFSs (hereafter Cass County-CC, Sargent County-SC, and Richland County-RC buffers) was evaluated and compared in the context of VFS design for feedlot runoff pollution control and management under agro-climatic condition of North Dakota. Buffer at CC feedlot was established with broadleaf or common cattail (Typha latifolia) grass filter, SC feedlot buffer had Garrison creeping foxtail (Alopecurus arundinaceus Poir.) and reed canary grass (Phalaris arundinaceus), and RC feedlot buffer had mixed grasses. Automatic samplers were installed to collect runoff samples at each inflow and outflow locations. Collected runoff samples were analyzed for total suspended solids (TSS), ortho-phosphorus (ortho-P), total phosphorus (TP), ammonium nitrogen $\left(\mathrm{NH}_{4}-\mathrm{N}\right)$, nitrate nitrogen $\left(\mathrm{NO}_{3}-\mathrm{N}\right)$, total Kjeldahl nitrogen (TKN), total nitrogen (TN), and potassium (K). Cass County (CC) VFS with cattails grass filter had the longest runoff-flow length $(65 \mathrm{~m})$ and resulted in better conducive environment for restricted TSS and TP transports reduction and better adsorption of ortho- $\mathrm{P}, \mathrm{NH}_{4}-\mathrm{N}$, and $\mathrm{K}$ compared to $\mathrm{SC}$ and $\mathrm{RC}$ feedlot buffers. Overall TSS, ortho-P, TP, $\mathrm{NH}_{4}-\mathrm{N}$, and $\mathrm{K}$ removal efficacies were $88 \%, 90 \%, 89 \%, 91 \%$, and $90 \%$, respectively, at CC VFS. At SC feedlot VFS resulted in the highest $\mathrm{NO}_{3}-\mathrm{N}$ reduction. Relatively poor performance was observed for the $\mathrm{RC}$ feedlot which was due to smaller runoff-flow length $(12 \mathrm{~m})$. Overall, CC feedlot outperformed the SC and RC VFSs in respect of TSS, ortho-P, TP, $\mathrm{NH}_{4}-\mathrm{N}, \mathrm{TKN} / \mathrm{TN}$ transport reductions.
\end{abstract}

Keywords: Vegetative filter strips; Feedlot; Runoff; Nutrients; Buffer performance; Solids; Pollution control

\section{Introduction}

Runoff from open animal feeding operations has long been known as a source of ground and surface water pollution. Runoff from feedlots may carry significant amount of manure borne nutrients (e.g. nitrogen and phosphorous), suspended matter, and pathogens to surface water [1-3]. According to Koelsch et al. [4], runoff from feedlots is a major contributor and will continue to be a contributor to surface and groundwater impairment. As per the North Dakota Department of Health 2010 integrated water quality assessment report, significant portion of the state's surface water is either threatened or does not support the aquatic life use due to excessive nutrient loadings. The report also indicated that primary sources of nutrient loadings in state's surface water are erosion and runoff from cropland, hydrologic modification, and runoff from animal feeding operations [5]. Nutrientladen water that enters into surface water causes eutrophication, a condition that decreases dissolved oxygen and kills aquatic animals. Additionally, increased in bacterial population, changed in water color, and odor development may affect recreational value. Mitigation of such pollution requires use of some practices or techniques that reduce the downstream discharge of nutrients contained in runoff from feedlots and land application sites.

Vegetative filter strips (VFS), also known as vegetative buffer strips (VBS) or simply buffer, are increasingly viewed as an attractive technology for improving the quality of runoff from pollutant source areas. However, different VFS designs exist either to meet the state regulatory needs or to reduce the installation costs. For an instance, beef cattle feedlots often use a lagoon or settling basin with vegetative filter strips to reduce runoff pollutant concentration and migration to surface water bodies [6]. Holding pond or lagoon construction is expensive, requiring large land area and regular maintenance. Moreover, seeping water from the containment structures possesses the risk of contamination of the potential drinking water [7]. On the other hand, VFS involves spreading and infiltration of runoff, thereby this system does not require any containment structure. The challenge of an effective VFS is to maintain the sheet flow; the systems fail if channelization occurs [8]. While the cost comparison between VFS and settling basin is difficult due to location, topography, and climatic conditions for both systems, but in general the cost involves in a VFS system is lower than other structures due to capital investment and maintenance $[9,10]$. As a result, producers are often not interested to construct holding ponds due to high capital investment, especially in North Dakota, where annual average precipitation ranged from 305 to $610 \mathrm{~mm}$. Instead, significant interest has grown in using VFS without sediment settling basin because of low installation and maintenance costs, as well as eliminating the acreage required for a settling basin. However, limited information is available on the performance of VFS depending on different buffer designs.

The main goal of this study was to evaluate a comparative Assessment or Performance of three different VFSs for its efficacy in removing solids and nutrients from the feedlot runoff under North Dakota climatic conditions and management practices.

\section{Materials and Methods}

Three existing feedlots were selected from different climatic regions of North Dakota (Figure 1), where VFSs design was slightly different

*Corresponding author: Shafiqur Rahman, Department of Agricultural and Biosystems Engineering, North Dakota State University, USA, Tel: +1 701231 8351; E-mail:s.rahman@ndsu.edu

Received November 16, 2012; Accepted December 27, 2012; Published January 07, 2013

Citation: Rahman A, Rahman S, Borhan MS (2013) Performance Evaluation of Three Vegetative Filter Strip Designs for Controlling Feedlot Runoff Pollution. J Civil Environ Eng 3: 124. doi:10.4172/2165-784X.1000124

Copyright: (c) 2013 Rahman A, et al. This is an open-access article distributed under the terms of the Creative Commons Attribution License, which permits unrestricted use, distribution, and reproduction in any medium, provided the original author and source are credited. 
and they were established at the end of feedlot to control runoff pollutants (Figure 2). These feedlots with buffer have been identified as Richland County (RC), Cass County (CC), and Sargent County (SC) buffer in North Dakota (Figure 2). The salient features of three VFSs were presented as follows:

\section{RC feedlot buffer}

The feedlot was designed for 500 head of beef cattle with two pens, but only one pen was operational, and runoff samples were collected

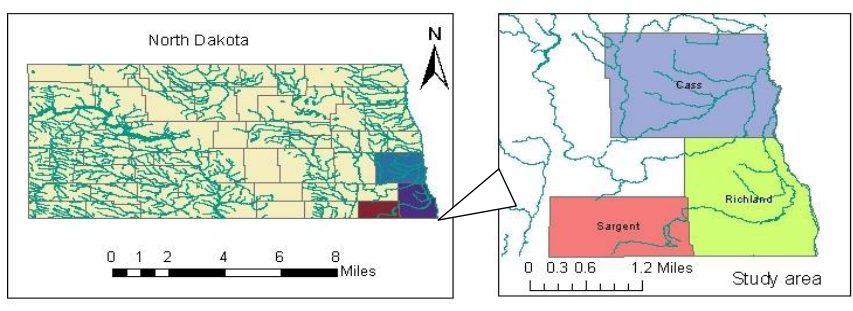

North Dakota County

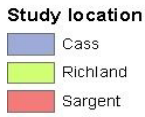

Figure 1: Locations of the study area.

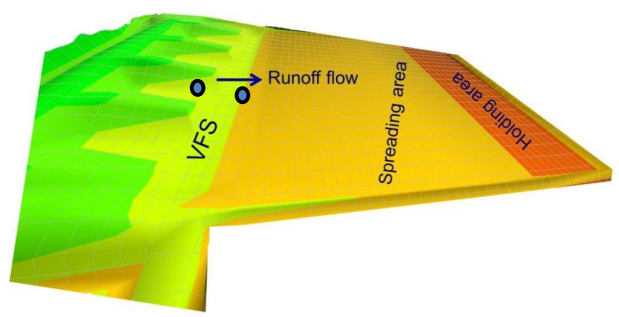

(a)

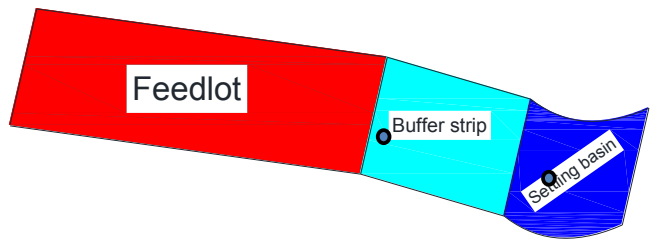

(b)

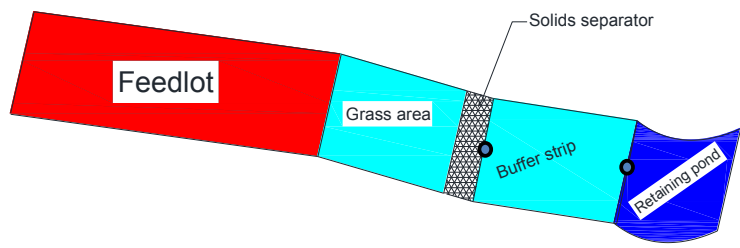

(c)

Figure 2: Layout of the feedlot, buffer, and water spreading area/settling basin a) RC feedlot without settling basin, b) CC feedlot with settling basin, and c) SC feedlot with solid separator. Small circles represent sampling locations. Figures are not to scale. from the operational pen only. The length and width of the pen were 76 and $62 \mathrm{~m}$, respectively, and overall aggregate slope of the feedlot about $5 \%$ was achieved by incorporating mounds in the pen. Feedlot had sandy loam soil and classified as hydrologic soil group A. A 12 $\mathrm{m}$ long (in the direction of flow) grass buffer strip was installed down slope of the feedlot with an assumption that runoff from the feedlot will pass through the buffer strip and maximize pollutant retention and then be dispersed evenly throughout the water spreading area (Figure 2a). The VFS consisted of mixed vegetation and it had uniform slope of $2 \%$. A detailed description of the VFS has been outlined in a previous paper [11].

\section{CC feedlot buffer}

Cass County (CC) feedlot is located at the North Dakota State University Beef Research Center. This feedlot has a dimension of 115 $\mathrm{m} \times 50 \mathrm{~m}$ with a maximum capacity 192 beef cattle. It had total six pens on clay soil and overall slope is about $5 \%$. A $65 \mathrm{~m}$ long and $115 \mathrm{~m}$ wide vegetative filter strip was constructed immediately after the feedlot pen surface and an alley that ran along the width of the feedlot. The VFS was seeded with common cattails grass and graded to a uniform slope of $2 \%$ on clay soil. A settling basin was constructed at the end of the VFS to contain run off exiting from the VFS (Figure $2 b$ ).

\section{SC feedlot buffer}

Sargent County (SC) feedlot buffer is a two-stage VFS (Figure 2c). At the initial stage, runoff from the feedlot ran through an approximately $165 \mathrm{~m}$ long narrow grassed area and reached to a solids separator. Then in second stage, runoff from the solids separator was channeled through a pipe and spreaded onto a vegetative filter strip. The vegetative filter strip was $40 \mathrm{~m}$ long in the direction of flow. Smooth bromegrass (Bromus inermis) and western wheatgrass (Pascopyrum smithii) were seeded for the grassed area and garrison creeping foxtail and reed canarygrass were seeded for the filter strips. The overall slope of the VFS was $2 \%$ and it was established on fine sandy loam soil. At the end, runoff exiting from the VFS was contained in a retaining pond and used for irrigating croplands. All three systems were designed to contain the runoff from 25 year 24-h rainfall event as state regulations required [12]. The average annual rainfall for RC, CC, and SC locations are about 468,494 , and $494 \mathrm{~mm}$ based on 21 years of average data.

\section{Sampling Runoff}

Each experimental site was equipped with automatic samplers (ISCO 6712, Teledyne ISCO Inc., Lincoln, NE) to collect runoff samples sequentially at one hour interval upon activation of the sampler. One sampler was installed to collect runoff at the entry of the VFS (hereafter inflow), and another sampler was installed at the exit of the VFS to collect runoff leaving the VFS (hereafter outflow). Samplers were powered by heavy duty marine batteries, which were charged by solar panel. Runoff in each sampling location was accumulated into a 60 liter bucket, and samples were collected from the bucket using ISCO samplers, which were activated via liquid level actuator (model: 1640, sampler actuator, Teledyne ISCO Inc., Lincoln, NE). The actuator sensor was installed inside the bucket at a height from the bottom of the bucket in such a way that the bucket had enough water to collect specified sample volume $(750 \mathrm{~mL})$. When automatic samplers malfunctioned, grab samples were collected from the bucket. After collecting runoff samples, buckets were emptied and reinstalled to collect runoff samples from the next runoff event. However, at CC location, outflow samples were collected manually from the runoff settling basin. Immediately after collection, samples were brought to laboratory and kept refrigerated until analyses. Temperature and 
precipitation data for each location were downloaded from a nearby weather station of North Dakota Agricultural Weather Network (NDAWN) during the study period.

\section{Sample Analysis}

Standard methods of analysis $[13,14]$ were employed to analyze runoff samples for determining nutrients and solids concentrations, $\mathrm{pH}$, and electrical conductivity (EC). Electrical conductivity and $\mathrm{pH}$ were analyzed using a handheld meter (YSI Pro Plus, YSI Inc., Ohio, USA). Solids and nutrients were analyzed at Soil Testing and Waste Management Laboratory of North Dakota State University.

For solids, method 2540B was used for TS and method 2540D was used for TSS as described in APHA [13]. Briefly, approximately $200 \mathrm{~mL}$ of an unfiltered liquid sample was evaporated in an oven at $105^{\circ} \mathrm{C}$ for $24 \mathrm{~h}$ or until a constant weight was reached to measure TS. Similarly, according to Method 2540D, a well-mixed runoff sample was filtered through a 0.45 micron glass fiber filter, and the unfiltered residue was heated at $105^{\circ} \mathrm{C}$ for $24 \mathrm{~h}$ to measure TSS.

For runoff nutrient concentration, runoff samples were measured for ortho-P, TP, $\mathrm{NH}_{4}-\mathrm{N}, \mathrm{NO}_{3}-\mathrm{N}, \mathrm{TKN}, \mathrm{TN}$, and $\mathrm{K}$. Methods/protocols used to analyze nutrient concentration of samples were summarized in Table 1. When measured concentration exceeded the detection limit of a particular parameter by a particular method/protocol, the runoff samples were diluted and reported values were multiplied by the dilution number. As a measure of quality control, calibration standards and blanks were analyzed along with the samples at every ten samples where appropriate. Later on, the efficacies of the VFSs were judged based on percent reduction of each analyte as measured using the following relationship:

$$
\eta_{\text {red }}=\frac{C_{i}-C_{o}}{C_{i}}
$$

where $\eta_{\text {red }}$ is reduction efficiency in percent (\%), $C_{i}$ is the inflow concentration of a particular analyte, and $C_{o}$ is the concentration of the same analyte in the outflow in $\mathrm{ppm}\left(\mathrm{mg} \mathrm{L}^{-1}\right)^{\circ}$.

\section{Statistical Analysis}

The effectiveness of VFSs in controlling/reducing solids (TS and TSS) and nutrients (TN, TKN, TP, ortho-P, $\mathrm{K}, \mathrm{NH}_{4}-\mathrm{N}$ and $\mathrm{NO}_{3}-\mathrm{N}$ ) were compared using Analysis of Variances (ANOVA) technique in the SAS environment [15]. The null hypothesis tested was that the mean concentrations of a parameter between inflow and outflow runoff for a particular year were equal. Yearly data were pooled and pairwise parameter means between inflow and outflow were compared using the Duncan's multiple range tests at $\mathrm{P} \leq 0.05$, if the main effect (inflow and outflow of VFS) was significant at $\mathrm{P} \leq 0.05$ for a parameter in the analysis of variance.

\section{Results and Discussion}

\section{Solids transport reduction}

Efficacies of VFSs at CC and SC feedlot locations in reducing TSS concentration were shown in figures $3(\mathrm{a})$ and $3(\mathrm{~b})$, respectively. Concentration of TSS was significantly lower at outflow than at inflow in $\mathrm{CC}$ feedlot $(\mathrm{P}<0.05)$. The TSS concentration in inflow varied from 0.01 to $3001 \mathrm{mgL}^{-1}$ while at the outflow varied from 0.02 to $259 \mathrm{mgL}^{-1}$. From figure $3 a$, it was shown that the TSS concentration in runoff fluctuated with rainfall magnitude, which accords with others findings where median pollutant load varied with rainfall magnitude [16].

In CC location, TSS transport reduction was usually high and a maximum $100 \%$ concentration reduction was considered when no flow exiting through the VFS following a rainfall event was observed. It is likely that decreased surface water flow resulted in deposition of sediment and absorbed potential pollutants [17]. The outflow concentrations at CC feedlot in 2011 were low due to the fact that samples were collected from the settling basin in which TSS might have been settled and diluted with runoff from the surrounding areas. Similarly, TSS concentration was significantly lower at outflow than that at inflow in SC feedlot, except for the few rain events. Concentration of TSS in inflow and outflow were ranged from 85.7 to $846 \mathrm{mgL}^{-1}$ and 89.3 to $1246 \mathrm{mgL}^{-1}$, respectively, at SC feedlot.

On two sampling events in SC feedlot, outflow TSS concentration was higher than the inflow concentration, which might have been attributed due to grab sampling from the bucket. On August 15 (2011) and June 20 (2012) grab samplings were performed at outflow locations followed by rain events. These grab samples might have contained high TSS because of diminishing runoff accumulated in sampling bucket (Figure 3b). In addition, on 29 May (Figure 3b), no inflow runoff sample was collected due to the malfunctioning of the sampler at inflow location and only outflow samples were collected.

At RC feedlot, average TSS concentration was significantly lower at outflow than that at inflow with inflow and outflow concentration varied from 61.9 to $3618 \mathrm{mgL}^{-1}$ and 35.5 to $1658 \mathrm{mgL}^{-1}$ [11], respectively. Overall, outflow TSS concentrations were significantly lower than the inflow concentrations. The results observed in this study are consistent with others [18], where they observed $26 \%$ to $95 \%$ reduction of TSS concentration in runoff from six beef feedlots in Iowa, USA. It is likely that the VFS provides a means of physical separation of suspended solids, reduces transport energy, deposits sediment, and increases infiltration of dissolved constituents into the VFS was also concluded by Hay et al. [19].

Table 1: Method/protocol used to analyze runoff sample from feedlots.

\begin{tabular}{|c|c|}
\hline Parameters (mg L-1) & Method/protocol used/Measurement range \\
\hline Ortho-P a & $\begin{array}{l}\text { QuikChem }{ }^{\circledast} \text { Method } 10-115-01-1-O \text { (Lachat Instruments, Loveland, CO) } \\
\text { Equivalent to EPA } 365.1 \text { method; 0-20 } \text { mg-1 }^{-1}\end{array}$ \\
\hline $\mathrm{NH}_{3}-\mathrm{N}$ a & $\begin{array}{l}\text { QuikChem }{ }^{\circledast} \text { Method } 10-107-06-1-J \text { (Lachat Instruments, Loveland, CO) } \\
\text { Equivalent to EPA } 350.1 \text { method; 0-20 } \text { gL L-1 }^{-1}\end{array}$ \\
\hline $\mathrm{NO}_{3}-\mathrm{N}$ a & $\begin{array}{l}\text { QuikChem }{ }^{\circledast} \text { Method 10-107-04-1-R (Lachat Instruments, Loveland, CO) } \\
\text { Equivalent to EPA } 353.2 \text { method; 0-20 } \text { mgL-1 }^{-1}\end{array}$ \\
\hline $\mathrm{K}^{\mathrm{b}}$ & Hach Method 8049 (Tetraphenylborate); 0-7 mgL-1; \\
\hline TP b & Hach Method 10127 (Molybdovanadate Method with Acid Persulfate Digestion); 1 -100 mgL-1; \\
\hline $\mathrm{TN}^{\mathrm{b}}$ & Hach Method 10072 (Acid Persulfate Digestion); 2 -150 $\mathrm{mgL}^{-1}$; \\
\hline TKN & APHA 2005 4500-N org C (Semi Micro Kjeldahl Method) \\
\hline
\end{tabular}

a Equivalent EPA methods

${ }^{b}$ USEPA approved for reporting 


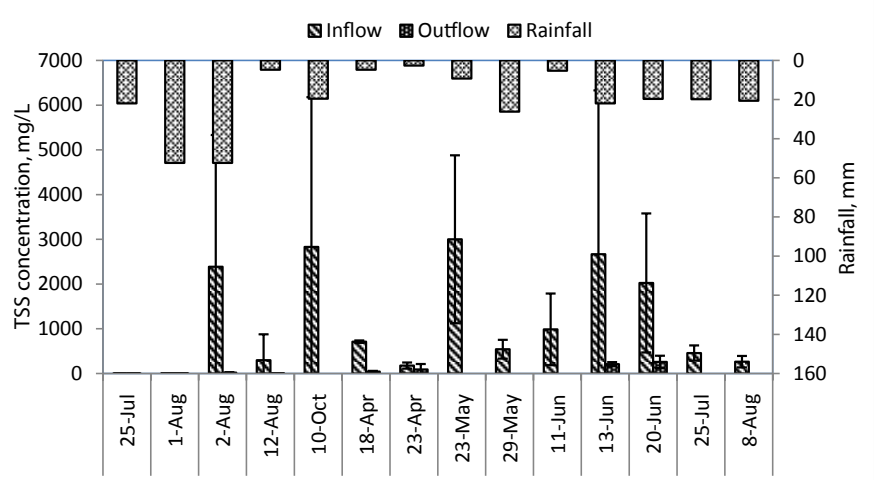

2011

2012

(a)

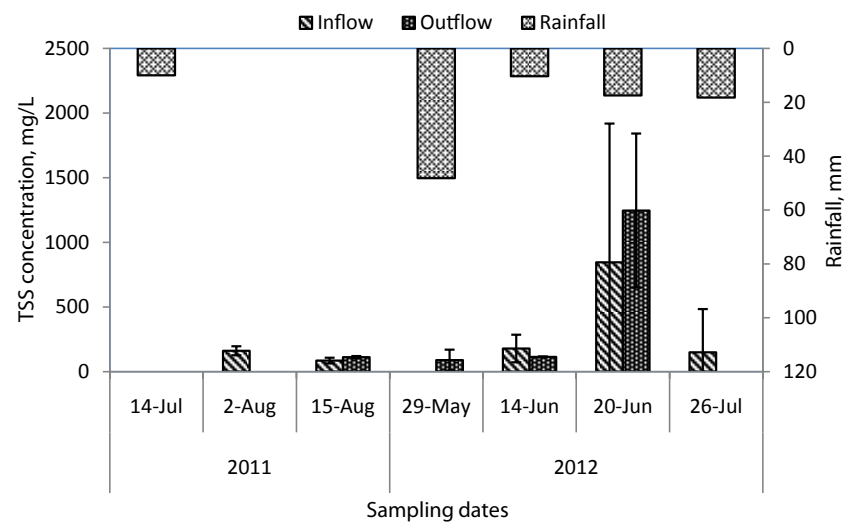

(b)

Figure 3: Average TSS concentration at inflow and outflow runoff samples at different sampling dates. Error bar represents standard deviation. (a) CC feedlot and (b) SC feedlot.

In CC feedlot buffer has broadleaf cattails which form dense stands of stems and leaves in various stages of development that might have created rough surfaces, impending sediment carrier energy, thus increased separation of solids. However, garrison creeping foxtail and Reed canary grasses in SC location and mixed vegetation at RC location found less effective in reducing TSS.

\section{Nutrient transport reduction}

Average ortho-P concentration ranged from 0.36 to $36.0 \mathrm{mgL}^{-1}$ at $\mathrm{CC}$ and 9.17 to $23.8 \mathrm{mgL}^{-1}$ at $\mathrm{SC}$ feedlots in inflow runoff samples as shown in figure $4 \mathrm{a}$ and $4 \mathrm{~b}$, respectively. Similarly, average ortho-P concentration ranged from 2.25 to $27.3 \mathrm{mgL}^{-1}$ at $\mathrm{RC}$ feedlot [11]. Outflow ortho-P concentration ranged from 0.0 to $5.10 \mathrm{mgL}^{-1}$ at CC, 3.33 to $20.2 \mathrm{mgL}^{-1}$ at SC, and 0.48 to $23.2 \mathrm{mgL}^{-1}$ at RC feedlots [11]. It was observed from the figure $4 \mathrm{a}$ that the concentrations of ortho-P at CC location in 2011 were comparatively low than that in 2012. This could be due to fewer animals were in the pens in 2011 as compared to 2012, and the feedlot was commissioned in 2011. When the feedlot was fully operational in 2012, ortho-P concentration in inflow runoff increased significantly, which might have also been contributed from previous year nutrient accumulation. The ortho-P fractions of $\mathrm{TP}$ were less in CC location and was usually below 0.35 compared to SC location where these fractions were up to 0.91 of TP (Figures 4 and 5). The average ortho-P fraction of TP was higher in RC location and the highest fraction found was 0.94 . It was noted that the ratio of ortho-P/ TP increased in the outflow compared to inflow for most of the runoff events indicating that particulate bound P was retained in the VFS with settled sediments. A small portion of soluble P tended to be captured by the buffer during low runoff flow rates with reduced concentrations at outflow.

Inflow TP concentrations ranged from 0.69 to $214 \mathrm{mgL}^{-1}$ at $\mathrm{CC}$ and 11.5 to $97.0 \mathrm{mgL}^{-1}$ at SC feedlot, and the outflow TP concentrations ranged from 0.22 to 28.5 and 8.03 to $96.8 \mathrm{mgL}^{-1}$, at $\mathrm{CC}$ and SC feedlots, respectively (Figures 5a-b). Rahman et al. [11] observed TP concentration range at inflow and outflow varied from 5.98 to 36.1 and 0.28 to $29.1 \mathrm{mgL}^{-1}$, respectively, at RC location. Higher TP concentrations in runoff samples were likely due to runoff collected immediately after the pen surface, where nutrient concentrations are typically higher. Also, soil characteristics might play some role for high TP concentration in runoff samples. For example, soil in CC and SC feedlot has greater finer fractions than that of RC feedlot, which might have carried greater TP load with runoff, as major part of $\mathrm{P}$ transport is assumed to occur with transport of finer particles in which they are attached with [20].

Other researchers also found that TP concentration in incoming runoff into the buffer varied from 20.0 to $81.5 \mathrm{mgL}^{-1}$ from a dairy facility, whereas ortho-P concentration varied from 16.2 to $54.6 \mathrm{mgL}^{-1}$ $[21,22]$. Andersen et al. [18] observed 53 to $222 \mathrm{mgL}^{-1}$ of TP and 28 to $101 \mathrm{mgL}^{-1}$ ortho-P concentrations in influent runoff to the VFS after passing through the settling basins.

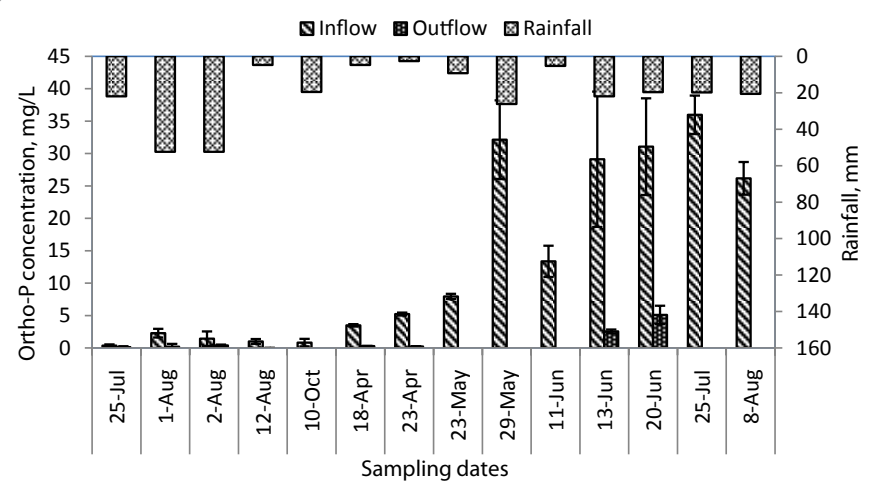

2011

(a)

2012

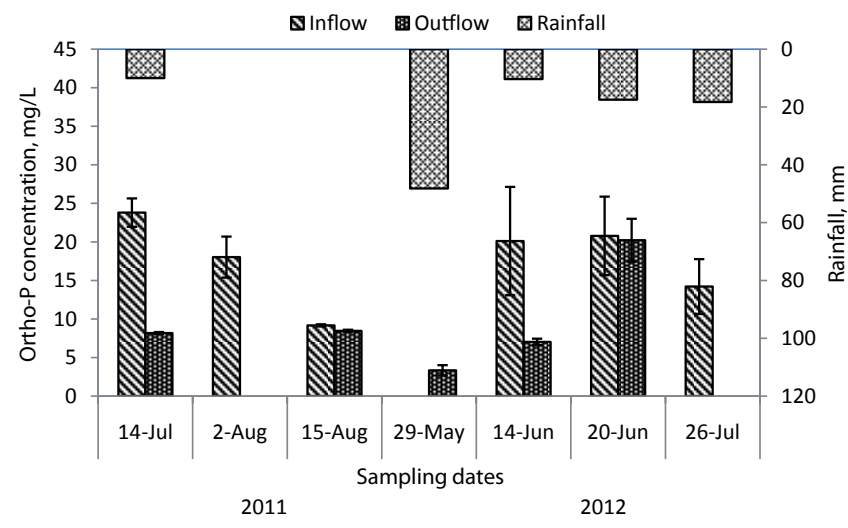

(b)

Figure 4: Average ortho-P concentration at inflow and outflow runoff samples at different sampling dates. Error bar represents standard deviation. (a) CC feedlot and (b) SC feedlot. 


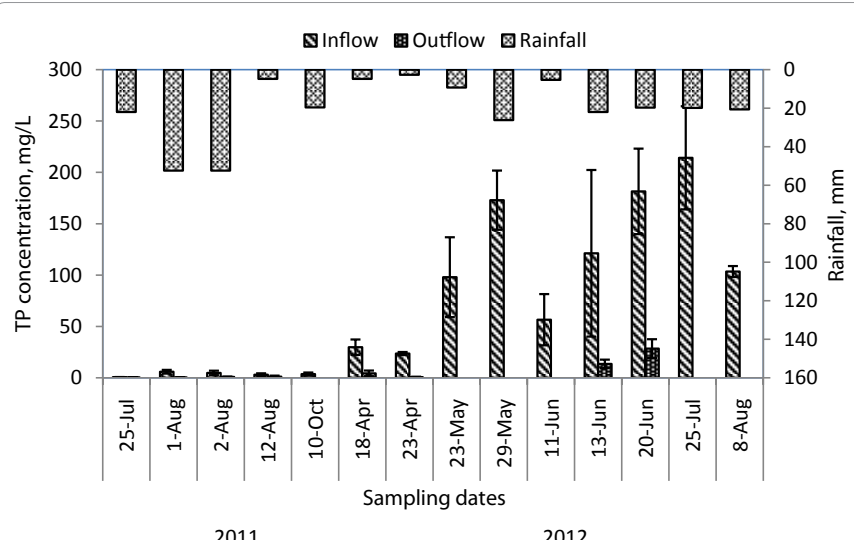

(a)

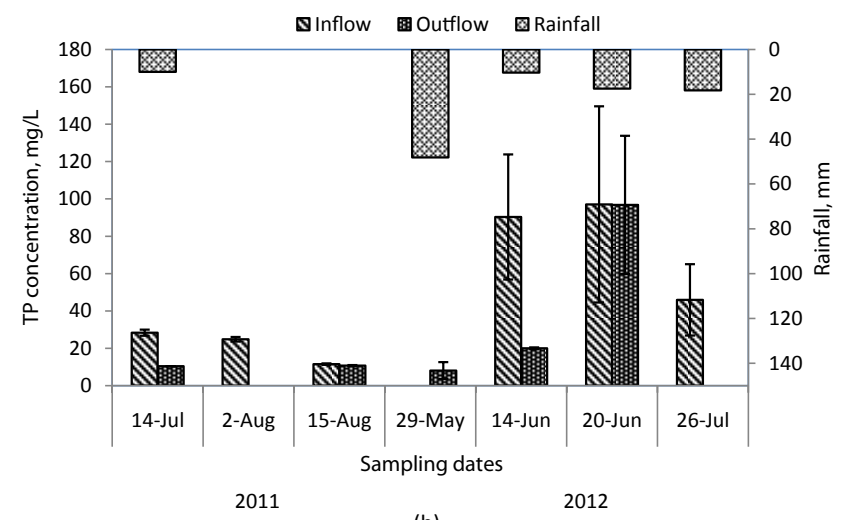

(b)

Figure 5: Average TP concentration at inflow and outflow runoff samples at different sampling dates. Error bar represents standard deviation. (a) CC feedlot and (b) SC feedlot.

Vegetative filter strip in CC feedlot was found very effective in reducing both ortho-P and TP concentrations from runoff than compared to filter strips in SC feedlot. Total phosphorus concentration reduction observed from as low as $57.8 \%, 0.27 \%$, and $4.02 \%$ in CC, SC, and RC [11] feedlots, respectively, to the highest $100 \%$ where there is no outflow exiting the filter strips. Similarly, ortho-P concentration reduction was $65.8 \%, 2.7 \%$, and $5.9 \%$ at CC, SC, and RC [11] feedlots, respectively, to the maximum $100 \%$ in the event of no outflow runoff from VFS occurred. Between rainfall events, when VFS soil was dry, it didn't generate any outflow from the buffer while it received inflow from the feedlot. This indicates that, with the time of rainfall occurrence and at low rainfall events, buffer is more effective due to antecedent soil moisture in the buffer area, which reduces runoff-flow and retained within buffer area.

Higher ortho-P reductions at CC feedlot was likely due to sorption to soil particles and plant materials, plant uptake, infiltration, and partly dilution for some runoff events. A similar phosphorus reduction trend has also been observed by other researchers. Andersen et al. [18], measured buffer performance from six beef feedlots in Iowa State, USA and observed TP concentration reductions ranged from 38\% to $94 \%$ and ortho-P concentration reductions ranged from $33 \%$ to $92 \%$.

Figures $6 \mathrm{a}$ and $\mathrm{b}$ show the average $\mathrm{NH}_{4}-\mathrm{N}$ concentrations during different sampling dates at CC and SC feedlots. Similar to ortho-P, concentrations of $\mathrm{NH}_{4}-\mathrm{N}$ in runoff at $\mathrm{CC}$ location were comparatively low in 2011 than that in 2012. Inflow $\mathrm{NH}_{4}-\mathrm{N}$ concentrations at CC and SC locations ranged from 0.78 to 64.6 and 0.09 to $30.2 \mathrm{mgL}^{-1}$ and outflow concentrations ranged from 0.17 to 4.70 and 2.15 to $23.1 \mathrm{mgL}^{-1}$, respectively. Similarly, inflow and outflow $\mathrm{NH}_{4}-\mathrm{N}$ concentrations at RC location ranged from 1.0 to 48.0 and 0.4 to $37.0 \mathrm{mgL}^{-1}$, respectively [11]. It was observed from the both figures that the $\mathrm{NH}_{4}-\mathrm{N}$ concentrations in inflow runoff samples were higher towards the end of monitoring period in 2012 than the earlier monitoring period, which might be due to higher microbial activity in manure and soil [16] at relatively higher temperatures during later part of the monitoring period, although microbial activity was not monitored in this study. Reduction of $\mathrm{NH}_{4}-\mathrm{N}$ concentration was found very high in both locations except 20 June, 2012 at SC, which was due to grab sampling. High $\mathrm{NH}_{4}-\mathrm{N}$ concentration reductions were likely due to the combined effect of soil sorption, and plant uptake [11].

Figures $7 \mathrm{a}$ and $\mathrm{b}$ show the $\mathrm{NO}_{3}-\mathrm{N}$ trends during different sampling dates at CC and SC feedlot locations, respectively. Comparatively, lower $\mathrm{NO}_{3}-\mathrm{N}$ concentration was observed at $\mathrm{CC}$ than that at SC location for most of the sampling dates. The $\mathrm{NO}_{3}-\mathrm{N}$ concentrations in inflow samples ranged from 0.04 to 6.16 and 2.58 to $73.6 \mathrm{mgL}^{-1}$ at CC and SC feedlot, whereas it varied from 0.01 to 8.05 and 0.13 to 17.8 $\mathrm{mgL}^{-1}$ at the outflow for $\mathrm{CC}$ and SC feedlot locations, respectively. The range of measured $\mathrm{NO}_{3}-\mathrm{N}$ concentrations at inflow and outflow at RC feedlot were undetectable limit to $6 \mathrm{mgL}^{-1}$ and undetectable to $54.3 \mathrm{mgL}^{-1}$, respectively. However, $\mathrm{NO}_{3}-\mathrm{N}$ concentrations were always below the EPA minimum allowable effluent discharge concentration

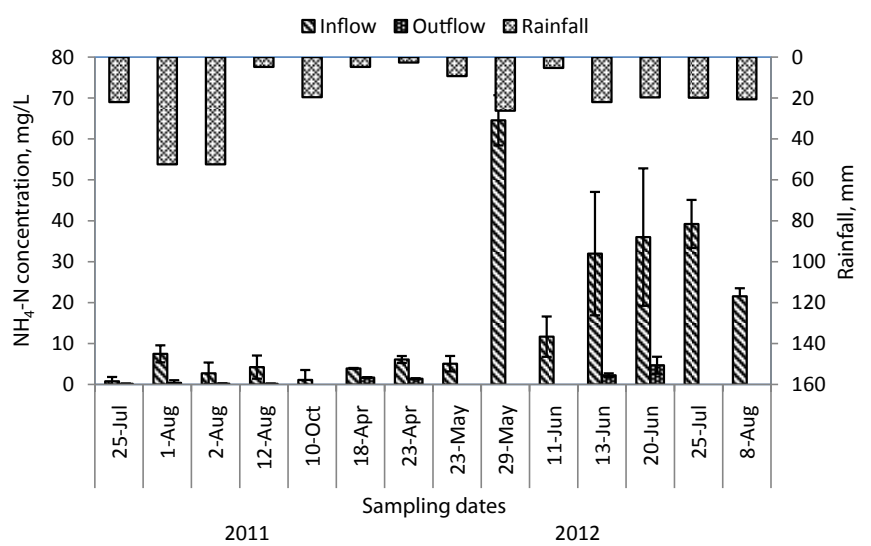

(a)

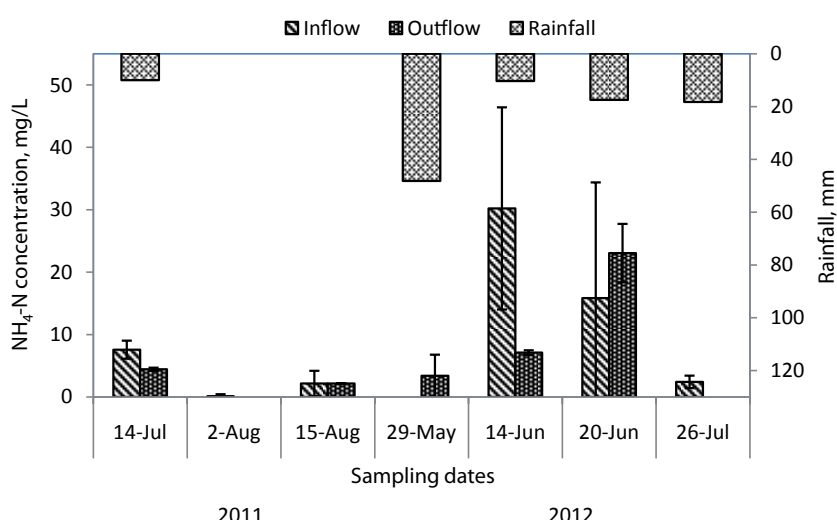

(b)

Figure 6: Average $\mathrm{NH}_{4}-\mathrm{N}$ concentration at inflow and outflow runoff samples at different runoff events. Error bar represents standard deviation. (a) CC feedlot and (b) SC feedlot. 


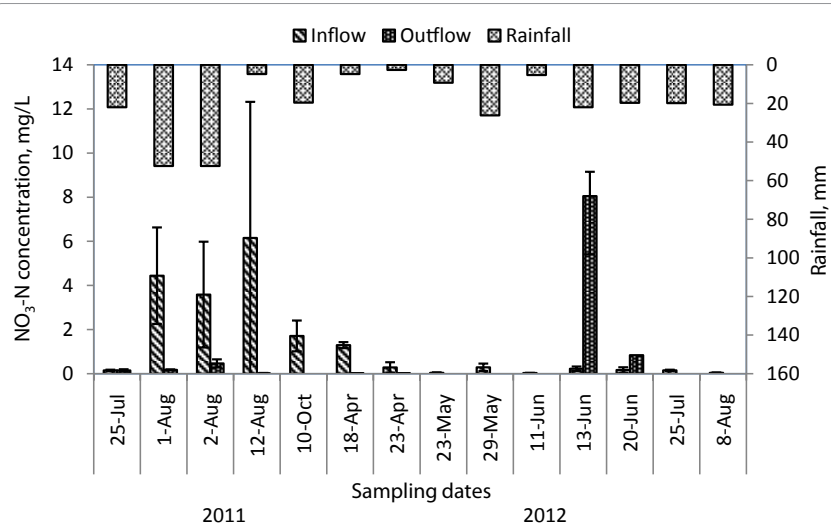

(a)

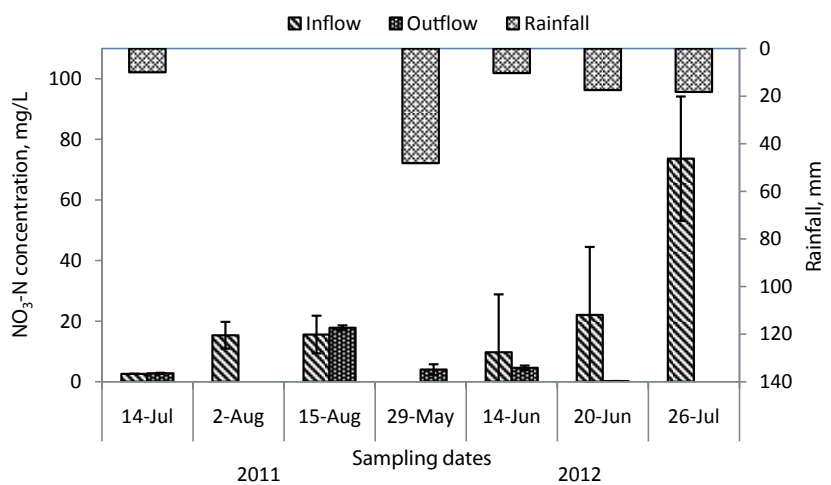

(b)

Figure 7: Average $\mathrm{NO}_{3}-\mathrm{N}$ concentration at inflow and outflow runoff samples at different rain events. Error bar represents standard deviation. (a) CC feedlot and (b) SC feedlot.

level of $10 \mathrm{mgL}^{-1}$ at CC feedlot location. At SC location, inflow $\mathrm{NO}_{3}-\mathrm{N}$ concentrations were higher than EPA threshold value on several occasions, but only in few occasion outflow concentrations were higher than EPA threshold value. This could impact downstream aquatic species and recreational uses. On 14 and 20 June, 2012 at CC and 14 July and 15 August, 2011 at SC locations, outflow $\mathrm{NO}_{3}-\mathrm{N}$ concentrations were higher than the inflow concentrations. This phenomenon has also been observed in many other studies [18, 2325 ], which are likely due to mineralization of particulate organic $\mathrm{N}$ that is trapped and accumulated in the buffer resulting in increased soluble $\mathrm{N}$ over time in outflow [24]. Comparing figures 6a with 7a and $6 \mathrm{~b}$ with $7 \mathrm{~b}$, it is observed that concentration of $\mathrm{NH}_{4}-\mathrm{N}$ and $\mathrm{NO}_{3}-\mathrm{N}$ in runoff has inverse relationship, increase in one decreases other are likely due to the biological nitrification [27]. This could be due to the microbial activities, and probably, $\mathrm{NO}_{3}-\mathrm{N}$ concentration depends on nitrifications.

Concentration of TKN or TN (TN measured for 2012 samples) showed similar trend as TSS (Figures $8 \mathrm{a}-\mathrm{b}$ ), and a correlation was found between the TS and TKN/TN $\left(\mathrm{R}^{2}=0.51\right.$ at CC, data and figure not shown). Dillaha et al. [24] also observed that $90 \%$ of TKN transport with sediment.

A strong correlation $\left(\mathrm{R}^{2}=0.70\right)$ between TKN and TS was also observed at RC feedlot [11]. Vegetative filter strips were very effective for reducing transport of TKN/TN for both CC and SC locations except on 20 June, 2012 at SC feedlot, which was due to grab sampling. Typical transport reduction mechanisms of TKN/TN are physical separation by sediment deposition and infiltration [28].

Concentrations of $\mathrm{K}$ at different sampling events at $\mathrm{CC}$ and SC feedlots are shown in figure 9. Potassium concentration at CC location was very low in 2011 but was found very high in 2012 (Figure 9a). Inflow concentration of $\mathrm{K}$ ranged from 12.3 to 2246 and 227 to $460 \mathrm{mgL}^{-1}$ and that at outflow ranged from 8.03 to 86.5 and 151 to $545 \mathrm{mgL}^{-1}$ at CC and SC feedlot locations, respectively. This value is slightly higher than that reported by Clark et al. [29], where they found the highest $\mathrm{K}$ concentration of $1864 \mathrm{mg} / \mathrm{L}$ in Mead, NE. Dickey and Vandeholm [30] used a settling basin after the beef feedlot and reported $\mathrm{K}$ concentrations at the entry and exit of a VFS were 665 and $168 \mathrm{mgL}$ ${ }^{1}$, respectively, and these are consistent with the values of $\mathrm{K}$ that were found in SC feedlot. Potassium is highly soluble and a high correlation $\left(\mathrm{R}^{2}=0.83\right)$ was found between the $\mathrm{K}$ concentration and difference of TSS and TS at CC feedlot (data not shown). However, a weak correlation $\left(R^{2}=0.32\right)$ exists between $K$ and electrical conductivity in the same location (data not shown). Despite of high $\mathrm{K}$ concentration in inflow runoff, the VSF system is appeared to be effective in reducing transport of K downstream, except on 20 June, 2012 at SC feedlot location, which may be due to variation of sampling methods (automatic VS. grab). Potassium is very soluble and its removal mechanism predominantly through infiltration, which is effectively done during some runoff events where there was no outflow beyond the filter strips.

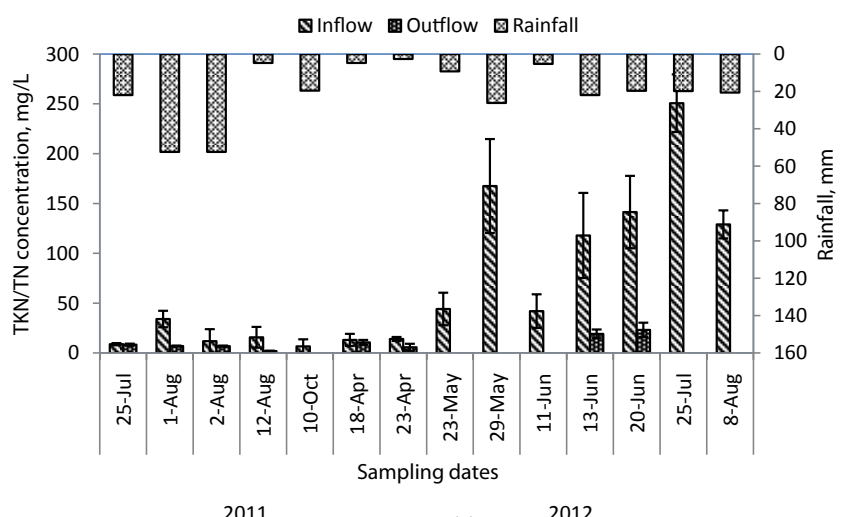

(a) 2012

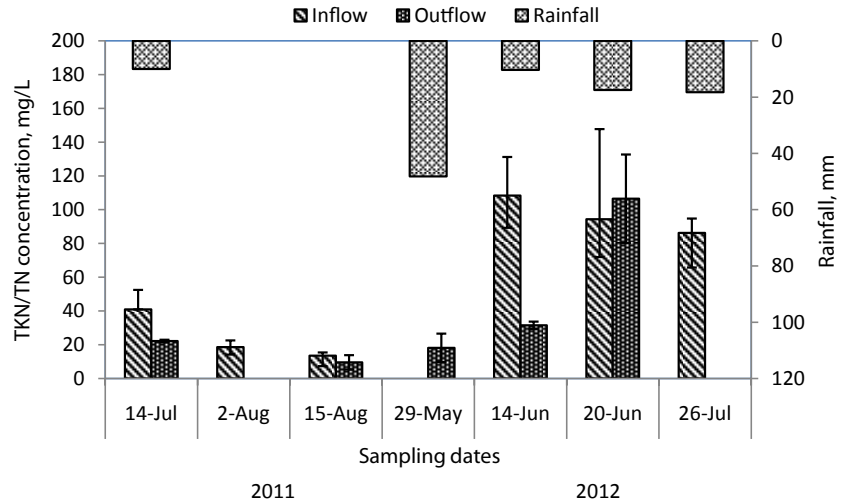

(b)

Figure 8: Average TKN/TN concentration at inflow and outflow runoff samples at different rain events. Error bar represents standard deviation. (a) CC feedlot and (b) SC feedlot. 


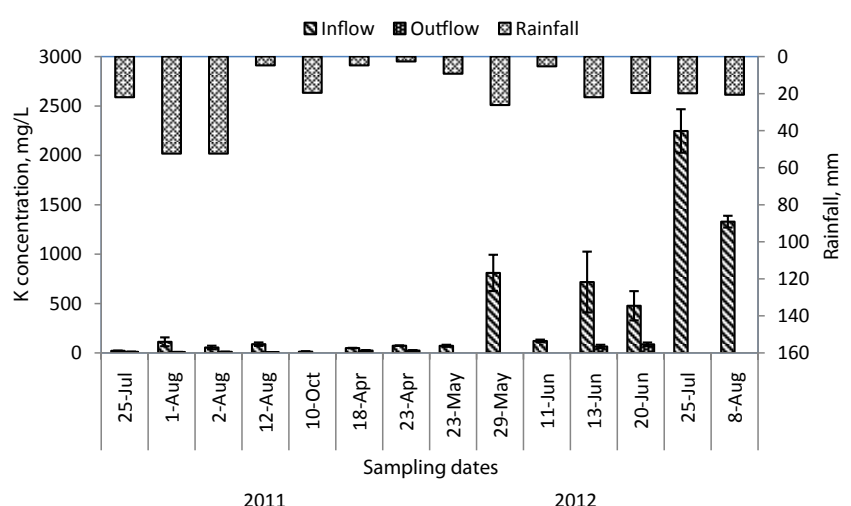

(a)

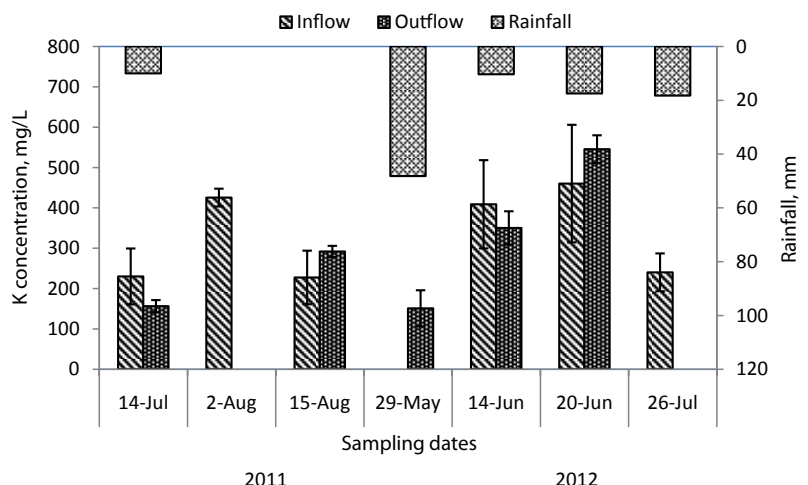

(b)

Figure 9: Average $\mathrm{K}$ concentration at inflow and outflow runoff samples at different rain events. Error bar represents standard deviation. (a) CC feedlot and (b) SC feedlot.

\section{Comparative performance of different buffer designs}

Overall performance of VFSs with different designs is presented in Tables 2,3 and 4 for CC, SC, and RC feedlot locations, respectively. In terms of solids concentration reductions, CC VFS system was most effective, followed by RC and SC VFS system. Total solids and TSS concentration reductions were $91.7 \%$ and $99.7 \%$ in 2011 and $72.2 \%$ and $88.3 \%$ in 2012 , respectively, at CC VFS system. Concentration reductions of the corresponding parameters at RC feedlot were $33.7 \%$ and $68 \%$ and at SC were $24 \%$ and $25.2 \%$ in 2011 and $-104 \%$ and $3.07 \%$ in 2012, respectively. High solids removal at CC VFS system was due to physical separation by vegetation through deposition, settling of solids as time progressed, as well as dilution. The broadleaf cattails used in CC VFS formed a dense stand of stems and leaves, which increased hydraulic roughness, decreasing water velocity, and hence, reduced sediment carrying capacity of water [31]. At SC VFS, low TSS concentration reduction was probably due to the low inflow TSS concentrations as runoff travelled a $165 \mathrm{~m}$ grassed area before entering into the VFS, and VFS is not very effective when inflow TSS concentration is low [32]. Increase in TS in outflow may be due to the contribution of dissolved salts from soil of VFS, which was supported by an increase in electrical conductivity in outflow runoff (Table 3 ).

Ortho-P and TP removal efficacies were the highest for the CC VFS, followed by SC and RCVFSs. Overall ortho-P and TP removals efficacies were approximately $85 \%$ and $90 \%$ in 2011 and 2012, respectively, at CC VFS. At SC VFS, overall ortho-P and TP concentrations reduction were $63 \%$ and $68 \%$ for 2012 and 55\% and 52\% during 2011, respectively.
However, ortho-P and TP concentration reductions were relatively low (19.3\% and $29.9 \%$, respectively) at RC VFS. It is well known that $\mathrm{P}$ adsorption to soil depends on the amount of clay minerals, Al- and Fe-oxides, calcium carbonate, and organic matter [33], the CC VFS appeared to be more effective compared to other two locations as CC VFS was on clay soil. Longer runoff flow-length, dense vegetation, and soil type could be the factors that made CC VFS more effective than SC and CC VFS systems. For the same reason, probably VFS at RC was lesser effective than the CC and SC.

Vegetative buffer strips were not always effective for all forms of nitrogen such as $\mathrm{NO}_{3}-\mathrm{N}$. Nitrate nitrogen is highly soluble in water, negatively charged ion (anion), and not attracted by soil particles to be captured by vegetation while flowing through a filter strip. For example, $\mathrm{NO}_{3}-\mathrm{N}$ concentration at the outflow increased compared to inflow at CC and RC VFSs, which is also reported in many previous studies $[24,34,35]$ with similar VFSs configuration. In contrast, SC feedlot resulted in $19 \%$ and $88.6 \% \mathrm{NO}_{3}-\mathrm{N}$ reduction in outflow runoff in 2011 and 2012, respectively. Thus, this result indicated that a grassed area located at upstream of a VFS may be appropriate for capturing $\mathrm{NO}_{3}-\mathrm{N}$ contained in feedlot runoff inflow.

In contrast, VFS systems were found very effective in reducing transport of $\mathrm{NH}_{4}-\mathrm{N}, \mathrm{TKN}$, and $\mathrm{TN}$. Unlike $\mathrm{NO}_{3}-\mathrm{N}, \mathrm{NH}_{4}-\mathrm{N}$ concentrations were consistently reduced to some extent in all three VFSs since ammonium $\left(\mathrm{NH}_{4}^{+}\right)$is a positively charged ion and held by the negatively charged suspended soil particles (Tables 2,3 and 4) to be captured by vegetation. The $\mathrm{CC}$ feedlot showed highest reductions in $\mathrm{NH}_{4}-\mathrm{N}$ concentration compared to $\mathrm{SC}$ and $\mathrm{RC}$ feedlots. This was likely due to densely populated broadleaf cattails vegetation that captured highest TS and TSS attributed to solids borne nutrients capture. The highest TKN/TN reductions were approximately 59\% and 85\% in 2011 and 2012, respectively, at CC feedlot VFS (Table 2). At SC feedlot VFS, estimated TKN/TN reductions were approximately $26 \%$ and $63 \%$ in 2011 and 2012, respectively, (Table 3). Similarly, at RC feedlot VFS, an estimated TKN reduction was approximately 36\% in 2010 (Table 4). Very low K transport reduction was observed except in CC feedlot VFS. The highest concentration reduction observed was $90.3 \%$ at CC whereas lowest concentration reduction was $19.8 \%$ at RC VFS. Potassium is highly soluble and less effective in transport reductions, which is also indicated by low reduction in EC values. The system which can infiltrate more water is the most effective in reducing $\mathrm{K}$ transport. At CC VFS, longer VFS with low antecedent moisture content was favorable for higher reduction effectiveness.

Nutrient transport reduction depends on deposition, adsorption to soil, infiltration, and plant uptake. Relatively poor performance of RC VFS was probably due to smallest runoff-flow length $(12 \mathrm{~m})$ among three VFSs. If runoff-flow length is longer, runoff will have longer time to travel and it will facilitate infiltration and better adsorption to soil. Among the three VFS systems, VFS system at CC location had the greatest runoff-flow length and resulted in better performance. Also, buffer with dense broadleaf cattails grass might be intercepted runoff flow and deposited solids in the VFS area. Since use of feedlot runoff water is restricted due to high concentration of nitrogen, salinity, or sodium content [36], water that passed through the reasonable buffer length and stored in a settling basin would be suitable for field irrigation. Vegetative filter strips at RC feedlot might possess some concern at downstream due to high nutrient concentration even after passing through buffer strips. A longer buffer strips and better vegetation might improve the situation. 
Citation: Rahman A, Rahman S, Borhan MS (2013) Performance Evaluation of Three Vegetative Filter Strip Designs for Controlling Feedlot Runoff Pollution. J Civil Environ Eng 3: 124. doi:10.4172/2165-784X.1000124

Page 8 of 9

Table 2: Concentration of different parameters averaged across entire sampling dates followed by standard deviations of the runoff samples at CC feedlot.

\begin{tabular}{|c|c|c|c|c|c|c|c|c|c|c|}
\hline & 2011 & & & & & 2012 & & & & \\
\hline Variable & Inflow & $\mathrm{N}$ & Outflow & $N$ & $\%$ reduction & Inflow & $\mathrm{N}$ & Outflow & $N$ & $\%$ reduction \\
\hline $\mathrm{pH}$ & $8.03 b \pm 0.5$ & 55 & $9.50 \mathrm{a} \pm 0.3$ & 9 & -18.2 & $7.37 a \pm 0.3$ & 121 & $7.16 b^{*} \pm 0.1$ & 33 & 2.75 \\
\hline $\mathrm{EC}, \mu \mathrm{Scm}^{-1}$ & $701 a \pm 501$ & 55 & $366 b \pm 46$ & 9 & 47.8 & $4740 a \pm 2873$ & 121 & $1074 b \pm 314$ & 33 & 77.3 \\
\hline $\mathrm{TS}, \mathrm{mgL}^{-1}$ & $2445 a \pm 3003$ & 65 & $202 b \pm 57.7$ & 14 & 91.7 & $4396 a \pm 2714$ & 121 & $1222 b \pm 485$ & 33 & 72.2 \\
\hline $\mathrm{TSS}, \mathrm{mg} / \mathrm{L}^{-1}$ & $1623 a \pm 3024$ & 65 & $5.13 a \pm 7.6$ & 14 & 99.7 & $1296 a \pm 1631$ & 121 & $151 b \pm 124$ & 33 & 88.3 \\
\hline Ortho-P, $\mathrm{mgL}^{-1}$ & $1.21 \mathrm{a} \pm 0.8$ & 65 & $0.18 b \pm 0.3$ & 14 & 85 & $22.0 \mathrm{a} \pm 13$ & 121 & $2.21 b \pm 2.2$ & 33 & 89.9 \\
\hline $\mathrm{TP}, \mathrm{mgL}^{-1}$ & $3.94 a \pm 2.0$ & 65 & $0.59 b \pm 0.6$ & 14 & 85.1 & $121 a \pm 73$ & 121 & $13.0 b \pm 12$ & 33 & 89.2 \\
\hline $\mathrm{NH}_{4}-\mathrm{N}, \mathrm{mgL}^{-1}$ & $3.33 a \pm 3.3$ & 65 & $0.26 b \pm 0.4$ & 14 & 92.3 & $29.4 a \pm 24$ & 121 & $2.64 b \pm 1.7$ & 33 & 91.0 \\
\hline $\mathrm{NO}_{3}-\mathrm{N}, \mathrm{mgL}^{-1}$ & $3.84 a \pm 4.1$ & 65 & $0.20 b \pm 0.2$ & 14 & 94.8 & $0.33 b \pm 0.4$ & 121 & $2.44 a \pm 3.8$ & 33 & -631 \\
\hline TKN/TN, mgL-1 & $14.70 \mathrm{a} \pm 13$ & 65 & $6.10 b \pm 2.4$ & 14 & 58.5 & $105 a \pm 74$ & 121 & $15.9 b \pm 7.7$ & 33 & 84.9 \\
\hline $\mathrm{K}, \mathrm{mgL}^{-1}$ & $59.4 a \pm 43$ & 65 & $9.59 b \pm 1.5$ & 14 & 83.8 & $536 a \pm 547$ & 121 & $52.0 b \pm 30$ & 33 & 90.3 \\
\hline
\end{tabular}

*Averages within a row followed by different letters are significantly different at $\mathrm{P} \leq 0.05$ according to Duncan multiple range tests

Table 3: Concentration of different parameters averaged across entire sampling dates followed by standard deviations of the runoff samples at SC feedlot.

\begin{tabular}{|c|c|c|c|c|c|c|c|c|c|c|}
\hline \multirow[b]{2}{*}{ Variable } & \multicolumn{5}{|l|}{2011} & \multicolumn{5}{|l|}{2012} \\
\hline & Inflow & $\mathrm{N}$ & Outflow & $\mathrm{N}$ & $\begin{array}{l}\% \\
\text { reduction }\end{array}$ & Inflow & $\mathrm{N}$ & Outflow & $\mathrm{N}$ & $\%$ reduction \\
\hline $\mathrm{pH}$ & $8.23 a \pm 0.2$ & 29 & $8.29 a \pm 0.1$ & 7 & -0.67 & $7.14 a \pm 1.2$ & 45 & $7.48 b^{*} \pm 0.2$ & 34 & -4.76 \\
\hline $\mathrm{EC}, \mu \mathrm{Scm}^{-1}$ & $2120 a \pm 234$ & 29 & $1771 b \pm 7.6$ & 7 & 16.5 & $2534 b \pm 866$ & 45 & $5544 a \pm 2067$ & 34 & -119 \\
\hline $\mathrm{TS}, \mathrm{mgL}^{-1}$ & $1750 a \pm 526$ & 29 & $1330 \mathrm{a} \pm 42$ & 4 & 24 & $2735 b \pm 1375$ & 44 & $5584 a \pm 1874$ & 33 & -104 \\
\hline $\mathrm{TSS}, \mathrm{mg} / \mathrm{L}^{-1}$ & $150 a \pm 43$ & 29 & $112 a \pm 8.6$ & 4 & 25.2 & $301 a \pm 561$ & 45 & $292 a \pm 500$ & 34 & 3.07 \\
\hline Ortho-P, $\mathrm{mgL}^{-1}$ & $23.3 a \pm 5.0$ & 29 & $10.6 b \pm 0.3$ & 7 & 54.7 & $18.6 a \pm 6.4$ & 45 & $6.86 b \pm 6.4$ & 34 & 63.1 \\
\hline $\mathrm{TP}, \mathrm{mgL}^{-1}$ & $17.4 \mathrm{a} \pm 4.5$ & 29 & $8.33 b \pm 0.2$ & 7 & 52.1 & $79.1 \mathrm{a} \pm 40$ & 45 & $25.3 b \pm 36$ & 34 & 68.0 \\
\hline $\mathrm{NH}_{4}-\mathrm{N}, \mathrm{mgL}^{-1}$ & $4.15 a \pm 3.2$ & 29 & $3.36 a \pm 2.2$ & 7 & 19.2 & $19.5 a \pm 19$ & 45 & $7.40 b \pm 8.0$ & 34 & 62.1 \\
\hline $\mathrm{NO}_{3}-\mathrm{N}, \mathrm{mgL}^{-1}$ & $14.0 \mathrm{a} \pm 5.9$ & 29 & $11.4 \mathrm{a} \pm 8.1$ & 7 & 19.0 & $30.2 a \pm 34$ & 45 & $3.45 b \pm 2.1$ & 34 & 88.6 \\
\hline TKN/TN, mgL-1 & $20.2 \mathrm{a} \pm 8.7$ & 29 & $15.0 \mathrm{a} \pm 7.4$ & 7 & 25.9 & $97 a \pm 35$ & 45 & $35.6 b \pm 35$ & 34 & 63.3 \\
\hline $\mathrm{K}, \mathrm{mgL}^{-1}$ & $378 a \pm 92$ & 29 & $234 b \pm 74$ & 7 & 38.1 & $362 a \pm 147$ & 45 & $253 b \pm 160$ & 34 & 30.3 \\
\hline
\end{tabular}

${ }^{*}$ Averages within a row followed by different letters are significantly different at $\mathrm{P} \leq 0.05$ according to Duncan multiple range tests

Table 4: Concentration of different parameters averaged across entire sampling dates followed by standard deviations of the runoff samples at RC feedlot (Rahman et al. 2012).

\begin{tabular}{|c|c|c|c|c|c|}
\hline & 2010 & & & & \\
\hline Variable & Inflow & $\mathrm{N}^{*+}$ & Outflow & $\mathrm{N}$ & $\%$ reduction \\
\hline $\mathrm{pH}$ & $7.69^{\mathrm{a}^{*}} \pm 0.29$ & 187 & $7.69 a \pm 0.29$ & 216 & - \\
\hline $\mathrm{EC}, \mu \mathrm{S} / \mathrm{cm}^{-1}$ & $2084 a \pm 782$ & 187 & $1761 b \pm 956$ & 217 & - \\
\hline $\mathrm{TS}, \mathrm{mg} / \mathrm{L}^{-1}$ & $3703 a \pm 1937$ & 187 & $2454 b \pm 1422$ & 218 & 33.7 \\
\hline $\mathrm{TSS}, \mathrm{mg} / \mathrm{L}^{-1}$ & $1252 a \pm 1704$ & 181 & $401 b \pm 686$ & 218 & 68.0 \\
\hline Ortho-P, mg/L-1 & $17.2 \mathrm{a} \pm 7.4$ & 173 & $13.9 b \pm 8.0$ & 196 & 19.3 \\
\hline $\mathrm{TP}, \mathrm{mg} / \mathrm{L}^{-1}$ & $25.1 \mathrm{a} \pm 8.8$ & 177 & $17.6 b \pm 10.4$ & 215 & 29.9 \\
\hline $\mathrm{NH}_{4}-\mathrm{N}, \mathrm{mg} / \mathrm{L}^{-1}$ & $13.8 \mathrm{a} \pm 11.4$ & 173 & $9.43 b \pm 10.1$ & 216 & 31.8 \\
\hline $\mathrm{NO}_{3}-\mathrm{N}+\mathrm{NO}_{2}-\mathrm{N}, \mathrm{mg} / \mathrm{L}^{-1}$ & $1.45 a \pm 2.89$ & 173 & $1.90 \mathrm{a} \pm 2.59$ & 196 & - \\
\hline $\mathrm{TKN}, \mathrm{mg} / \mathrm{L}^{-1}$ & $112 a \pm 56.1$ & 177 & $72.5 b \pm 57.1$ & 215 & 35.6 \\
\hline $\mathrm{K}, \mathrm{mg} / \mathrm{L}^{-1}$ & $5074 a \pm 237$ & 177 & $406 \mathrm{~b} \pm 281$ & 216 & 19.8 \\
\hline
\end{tabular}

${ }^{*}$ Averages within a row followed by different letters are significantly different at $\mathrm{P} \leq 0.05$ according to Duncan multiple range tests $\mathrm{N}^{* *}$ - number of samples

\section{Conclusions}

Vegetative filters reduced solids and nutrients from feedlots runoff to some extent. Degree of pollutants removal was dependent upon the type of vegetation and runoff-flow length of a filter strip. For $\mathrm{NO}_{3}-\mathrm{N}$ concentration reduction, SC feedlot was found more effective than CC and RC feedlots, which was due to differences in vegetative filter systems. Relatively inferior performance of RC feedlot buffer compared to CC and SC was probably due to smallest runoff-flow length $(12 \mathrm{~m})$ among three VFSs. Overall, CC feedlot with longer flow length $(65 \mathrm{~m})$, dense broadleaf cattail grass filter bed outperformed the SC and RC VFSs in respect of TSS, ortho-P, TP, $\mathrm{NH}_{4}-\mathrm{N}, \mathrm{TKN} / \mathrm{TN}$ reductions.

\section{References}

1. Swanson NP, Mielke NL, Lorimor JC, McCalla TM, Allis JR (1971) Transport of pollutants from sloping cattle feedlots as affected by rainfall intensity, duration, and recurrance. Proceedings of the International Symposium of Livestock Wastes,ASAE, St. Joseph, MI, USA.

2. Laws E (1993) Aquatic Pollution: An Introductory Text, 2nd ed. : Wiley and Sons, New York.

3. Troeh FR, Hobbs JA, Donahue RL (2004) Water quality and pollution. in Soil and Water Conservation: for Productivity and Environmental Protection (4th edn)Prentice Hall: Upper Saddle River, New Jersey, USA. 523-550.

4. Koelsch RK, Lorimor JC, Mankin KR (2006) Vegetative treatment systems for management of open lot runoff: Review of literature. Applied Engineering in Agriculture 22: 141-153.

5. NDDoH (2010) North Dakota 2010 Integrated Section 305(b) Water Quality Assessment Report and Section 303(d) List of Waters Needing Total Maximum Daily Loads.

6. Mankin KR, Barnes PL, Harner JP, Kalita PK, Boyer JE (2006) Field evaluation 
Citation: Rahman A, Rahman S, Borhan MS (2013) Performance Evaluation of Three Vegetative Filter Strip Designs for Controlling Feedlot Runoff Pollution. J Civil Environ Eng 3: 124. doi:10.4172/2165-784X.1000124

Page 9 of 9

of vegetative filter effectiveness and runoff quality from unstocked feedlots. J Soil Water Conserv 61: 209-217.

7. Parker DB, Eisenhauer DE, Schulte DD, Nienaber JA (1999) Seepage characteristics and hydraulic properties of a feedlot runoff storage pond. Transactions of the ASAE. 42: 369-380.

8. Lorimor JC, Shouse S, Miller W (2002) Vegetative filter strips for open feedlot runoff treatment. In: Extension Bulletin PM 1919, lowa State University Press, Ames, lowa, USA.

9. Kizil U (2010) Comparison of alternative feedlot runoff management systems. African Journal of Agricultural Research 5: 236-242.

10. Barrett ME (1999) Complying with the Edwards Aquifer Rules: Technical Guidance on Best management Practices. Austin: Texas Natural Resource Commission.

11. Rahman A, Rahman S, Cihachek L (2012) Efficacy of vegetative filter strips (VFS) installed at the edge of feedlot to minimize solids and nutrients from runoff. Agric Eng Int: CIGR Journal 14

12. NDDoH (2005) North Dakota livestock program design manual. North Dakota Department of Health Bismarck, North Dakota, USA

13. APHA (2005) Standard Methods for Examination of Water Wastewater. 2nd ed Washington, D.C.: American Public Health Association.

14. Hach (2007). DR 2800 Spectrophotometer procedures manual (2ndeds) Hach Company Loveland.

15. SAS (2009) SAS version 9.1Cary, NC: SAS Institute Inc.

16. Duchemin M, Hogue R (2009) Reduction in agricultural non-point source pollution in the first year following establishment of an integrated grass/tree filter strip system in southern Quebec (Canada). Agriculture Ecosystems \& Environment 131: 85-97.

17. Stout WL, Pachepsky YA, Shelton DR, Sadeghi AM, Saporito LS, et al. (2005) Runoff transport of faecal coliforms and phosphorus released from manure in grass buffer conditions. Lett Appl Microbiol 41: 230-234.

18. Andersen DS, Berns RT, Moody LB, Khanijo I, Helmers M, et al. (2009) Performance of six vegetative treatment systems for controlling runoff from open beef feedlots in lowa. American Society of Agricultural and Biological Engineers, St. Joseph, Michigan, USA.

19. Hay V, Pittroff W, Tooman EE, Meyer D (2006) Effectiveness of vegetative filte strips in attenuating nutrient and sediment runoff from irrigated pastures. J Agri Sci 144: 349-360.

20. Sharpley AN, Chapra SC, Wedepohl R, Sims JT, Daniel TC, et al. (1994) Managing agricultural phosphorus for protection of surface waters - issues and options. J Environ Qual 23: 437-451.

21. Schwer CB, Clausen JC (1989) Vegetative filter treatment of dairy milkhouse wastewater. J Environ Qual 18: 446-451.
22. Schellinger GR, Clausen JC (1992) Vegetative filter treatment of dairy barnyard runoff in cold regions. J Environ Qual 21: 40-45.

23. Dillaha TA, Reneau RB, Mostaghimi S, Lee D (1989) Vegetative filter strips for agricultural nonpoint source pollution-control. Transactions of the ASAE 32 513-519.

24. Dillaha TA, Sherrard JH, Lee D, Mostaghimi S, Shanholtz VO (1988) Evaluation of vegetative filter strips as a best management practice for feed lots. Journal Water Pollution Control Federation 60: 1231-1238.

25. Mendez A, Dillaha TA, Mostaghimi S (1999) Sediment and nitrogen transport in grass filter strips. Journal of the American Water Resources Association 35: 867-875.

26. Young RA, Huntrods T, Anderson W (1980) Effectiveness of vegetated buffe strips in controlling pollution from feedlot runoff. J Environ Qual 9: 483-487.

27. Kim JR, Zuo Y, Regan JM, Logan E (2008) Analysis of ammonia loss mechanisms in microbial fuel cells treating animal wastewater. Biotechno Bioeng 99: 1120-1127.

28. Vought LBM, Dahl J, Pedersen CL, Lacoursiere JO (1994) Nutrient retention in riparian ecotones. Ambio 23: 342-348.

29. Clark RN, Gilbertson CB, Duke HR (1975) Quantity and quality of beefyard runoff in the great planins. In: Managing Livestock Wastes, Proceedings of the Third International Symposium on Livestock Wastes, American Society of Agricultural Engineers, Michigan, USA.

30. Dickey EC, Vanderholm DH (1981) Vegetative filter treatment of livestock feedlot runoff. J Environ Qual 10: 279-284.

31. Mayer LD, Wischmeier WH (1969) Mathematical simulation of the process of soil erosion by water. Transactions of the ASAE 12: 754-758.

32. Srivastava P, Edwards DR, Daniel TC, Moore PA, Costello TA (1996) Performance of vegetative filter strips with varying pollutant source and filter strip lengths. Transactions of the ASAE 39: 2231-2239.

33. Svendsen LM (1992) Dynamics of phosphorus, organic nitrogen and organic matter in watercourses: Methods, retention, transport and models. In: Ministry of the Environment, National Environmental Research Institute, Denmark.

34. Chaubey I, Edwards DR, Daniel TC, Moore PA, Nichols DJ (1994) Effectiveness of vegetative filter strips in retaining surface-applied swine manure constituents. Transactions of the ASAE 37: 845-850.

35. Chaubey I, Edwards DR, Daniel TC, Moore PA, Nichols DJ (1995) Effectiveness of vegetative filter strips in controlling losses of surface-applied poultry litter constituents. Transactions of the ASAE 38: 1687-1692.

36. Butchbaker AF (1973) Feedlot runoff disposal on grass or crops. L 1053. in GPE-7521, Great Plains Beef Cattle Feeding Handbook, Texas Agricultura Extension Service, Texas A\&M University. 